\title{
Users evaluate a detailed familial risk questionnaire as valuable and no more time consuming than a simple enquiry in a web-based diabetes risk assessment tool
}

Citation for published version (APA):

Wijdenes, M., Henneman, L., Dondorp, W. J., Cornel, M. C., \& Timmermans, D. R. M. (2016). Users evaluate a detailed familial risk questionnaire as valuable and no more time consuming than a simple enquiry in a web-based diabetes risk assessment tool. Public Health, 130, 87-90. https://doi.org/10.1016/j.puhe.2015.06.003

Document status and date:

Published: 01/01/2016

DOI:

10.1016/j.puhe.2015.06.003

Document Version:

Publisher's PDF, also known as Version of record

Document license:

Taverne

Please check the document version of this publication:

- A submitted manuscript is the version of the article upon submission and before peer-review. There can be important differences between the submitted version and the official published version of record.

People interested in the research are advised to contact the author for the final version of the publication, or visit the DOI to the publisher's website.

- The final author version and the galley proof are versions of the publication after peer review.

- The final published version features the final layout of the paper including the volume, issue and page numbers.

Link to publication

\footnotetext{
General rights rights.

- You may freely distribute the URL identifying the publication in the public portal. please follow below link for the End User Agreement:

www.umlib.nl/taverne-license

Take down policy

If you believe that this document breaches copyright please contact us at:

repository@maastrichtuniversity.nl

providing details and we will investigate your claim.
}

Copyright and moral rights for the publications made accessible in the public portal are retained by the authors and/or other copyright owners and it is a condition of accessing publications that users recognise and abide by the legal requirements associated with these

- Users may download and print one copy of any publication from the public portal for the purpose of private study or research.

- You may not further distribute the material or use it for any profit-making activity or commercial gain

If the publication is distributed under the terms of Article $25 \mathrm{fa}$ of the Dutch Copyright Act, indicated by the "Taverne" license above, 


\title{
Short Communication
}

\section{Users evaluate a detailed familial risk questionnaire as valuable and no more time consuming than a simple enquiry in a web-based diabetes risk assessment tool}

\author{
M. Wijdenes ${ }^{a}$, L. Henneman ${ }^{b, *}$, W.J. Dondorp ${ }^{c}$, M.C. Cornel ${ }^{b}$, \\ D.R.M. Timmermans ${ }^{a}$ \\ ${ }^{a}$ Department of Public and Occupational Health, EMGO Institute for Health and Care Research, VU University \\ Medical Center, Amsterdam, The Netherlands \\ ${ }^{b}$ Department of Clinical Genetics, Section Community Genetics, EMGO Institute for Health and Care Research, \\ VU University Medical Center, Amsterdam, The Netherlands \\ ${ }^{c}$ Department of Health, Ethics and Society, Research Institutes CAPHRI and GROW, Maastricht University, \\ Maastricht, The Netherlands
}

A R T I C L E I N F O

Article history:

Received 11 December 2014

Received in revised form

3 June 2015

Accepted 5 June 2015

Available online 14 July 2015

\section{Introduction}

A diabetes family history assessment can be used as a tool to select high-risk groups, ${ }^{1}$ to personalize prevention messages ${ }^{1}$ and may change preventive behaviour among high-risk populations. $^{2-4}$ To predict diabetes risk, family history information is often incorporated in diabetes risk assessments in addition to other risk factors, such as age and being overweight. To collect a family history, several methods can be used, ranging from detailed and standardized instruments using a pedigree to a simple dichotomous enquiry (presence or absence of disease in any relative). It has been shown that a self-reported detailed family history identifies more individuals at familial risk than a simple dichotomous enquiry. ${ }^{4-6}$ Individuals arguably will be more triggered by a detailed assessment to reflect on affected relatives ${ }^{5}$ and may even be more inclined to contact relatives to confirm their disease status. However, a detailed family history assessment can be time consuming, and individuals may be more inclined to complete a tool that is short.

Although it has been shown that the great majority of people consider knowing their family's health history important to their personal health, ${ }^{8}$ little is known about how individuals actually perceive the value of familial risk information and consequently receiving tailored feedback on their risk. As part of a randomized controlled trial ${ }^{4}$ (PreDiCT study), aimed to determine the effect of tailored web-based diabetic familial risk information on risk-reducing behaviour, the present study addressed the following question: How do users (with or without a diabetes family history) of either a detailed diabetic familial risk assessment or a simple family history enquiry perceive the value and burden of a web-based diabetes risk assessment tool?

\footnotetext{
* Corresponding author. Dept. Of Clinical Genetics, Section Community Genetics, EMGO Institute for Health and Care Research, PO Box 7057, 1007 MB Amsterdam, The Netherlands. Tel.: +31 20 4449815; fax: +31 204448665.
}

E-mail address: 1.henneman@vumc.nl (L. Henneman). 


\section{Methods}

Participants in the PreDiCT trial ${ }^{4}$ (Trial NTR1938) were individuals with and without a family history of diabetes aged 35-65 years with a Body Mass Index $\left(B M I, k g / \mathrm{m}^{2}\right) \geq 25$, recruited from an independent certified research agency. Family history was defined as having $\geq 1$ first degree relative with diabetes. Participants were not aware of being selected because of their familial risk and were randomly assigned to the simple or detailed condition. Differences between these two conditions are presented in Box 1. All participants were informed that the study was to determine the best way to advise people about their diabetes risk and thus blinded for study groups. During the trial diabetes risk was assessed with a web-based version of the validated Diabetes Risk Test, ${ }^{9}$ including risk factors such as age, BMI, waist circumference, being physically active. Results were categorized in three risk strata ( 2 in 100, 10 in 100 and 20 in 100) that referred to their risk of getting diabetes within the next five years. Each participant received individual risk information based on the risk test, supported by riskreducing preventive measures. Familial risk was assessed as part of the Diabetes Risk Test, by means of: 1) a simple enquiry in the simple condition; and 2) by means of a detailed family history questionnaire in the detailed condition. In this study all participants who completed the baseline, the directly post-test follow-up and three months follow-up questionnaires were selected. In total, 554 received the detailed condition and 555 received the simple condition. Participants were asked directly after they performed the assessment how they evaluated the Diabetes Risk Test and corresponding information, using 7point semantic differential rating scales: useful, understandable, worrisome. The percentage of people who 'agreed' with the items was determined by a score of 5-7. The statements are shown in full length in Table 1. At three months, participants were asked in what way they agreed with two statements about the Diabetes Risk Test using a 5-point semantic differential rating scale: 1) I would recommend others to take the test; 2) completing the test takes a lot of time and effort. The percentage of people who 'agreed' with these items was determined by a score of four or five.

Potential group differences in the baseline characteristics of the study participants were assessed using chi-squared test for proportions and t-test for means. Logistic regression analyses were conducted to test for differences between users of each condition in perceived value and perceived burden.

\section{Results}

Of the 554 participants that received the detailed condition, 288 were people with and 266 were people without a family history of diabetes, and of the 555 participants that received the simple condition this was 286 and 269 respectively. There were no significant differences on the baseline characteristics sex, age, ethnicity ( $97 \%$ of native Dutch origin), education, BMI (33\% obese [BMI $\geq 30]$ ), and familial risk between individuals who received the detailed condition and those who received the simple condition.

Most participants perceived the detailed condition as useful, understandable and people would recommend it to others, see Table 1. Detailed familial risk assessment and feedback was associated with a lower perception that the information was worrisome than the simple enquiry (16.6\% versus $22.2 \%$, $P<0.05)$. No further differences were found between both conditions. Few participants perceived the burden of the test taking a lot of time and effort, even less so for the detailed condition, though not statistically significant. There were no differences in all findings between people with or without a family history, showing that this parameter was no effect modifier.

\section{Discussion}

The aim of this paper was to evaluate users' perceptions of a web-based diabetic risk assessment using a detailed family

Box 1

Differences in diabetes risk assessment and feedback information between the simple condition and the detailed condition.

\begin{tabular}{|c|c|c|}
\hline & Simple condition & Detailed condition \\
\hline Pre-assessment information & $\begin{array}{l}\text { - Main risk factors (not including family } \\
\text { history) } \\
\text { - Effectiveness of preventive options }\end{array}$ & $\begin{array}{l}\text { - Main risk factors, emphasising family history } \\
\text { (e.g. explaining that familial risk increases with } \\
\text { the number and kinship of affected relatives) } \\
\text { - Effectiveness of preventive options }\end{array}$ \\
\hline Family history assessment & $\begin{array}{l}\text { Simple enquiry: Participants were asked 'Does } \\
\text { diabetes occur within your family?' 1) no; 2) } \\
\text { yes, with my grandfather, grandmother, } \\
\text { uncle, aunt, nephew, niece; 3) yes, with my } \\
\text { father, mother, brother, sister, or child. }\end{array}$ & $\begin{array}{l}\text { Detailed questionnaire: First, participants had to } \\
\text { indicate the number of children and siblings, and } \\
\text { the number of both paternal or maternal aunts } \\
\text { and uncles. Subsequently, they could indicate for } \\
\text { each first-degree relative and second-degree } \\
\text { relative and whether these relatives had been } \\
\text { diagnosed with diabetes or whether they did not } \\
\text { know this. }\end{array}$ \\
\hline Feedback information & $\begin{array}{l}\text { - Individual risk based on the risk test } \\
\text { - Risk-reducing preventive measures }\end{array}$ & $\begin{array}{l}\text { - Individual risk based on the risk test } \\
\text { - Information about the total number of affected } \\
\text { relatives } \\
\text { - Risk-reducing preventive measures }\end{array}$ \\
\hline
\end{tabular}


Table 1 - Users' perceived value and burden of the detailed condition versus the simple condition.

\begin{tabular}{|c|c|c|c|}
\hline & $\begin{array}{c}\text { Simple condition } \\
(n=555) \\
\text { Agree }(\%)\end{array}$ & $\begin{array}{c}\text { Detailed condition } \\
(n=554) \\
\text { Agree }(\%)\end{array}$ & $P$-value \\
\hline \multicolumn{4}{|l|}{ The information ${ }^{a}$ was ... } \\
\hline Useful (pointless [1] - useful [7]) & 87.9 & 87.2 & .71 \\
\hline Understandable (hard to understand [1] - easy to understand [7]) & 93.7 & 93.5 & .90 \\
\hline Worrisome (not worrisome [1] - worrisome [7]) & 22.2 & 16.6 & .02 \\
\hline I would recommend others to take the Diabetes Risk Test & 61.6 & 59.6 & .48 \\
\hline Completing the Diabetes Risk Test takes a lot of time and effort & 2.3 & 2.0 & .68 \\
\hline
\end{tabular}

history assessment or a simple family history enquiry. Users of the detailed familial risk assessment and the simple enquiry evaluated the information correspondingly valuable, as both users regarded it as highly useful and understandable, without being too time consuming and had a moderate response to recommend take the diabetes risk test. Users of the detailed familial risk assessment experienced less feelings of worry than users of a simple enquiry.

Individuals who complete disease risk assessments are considered to be more interested and have more understanding of a tool that is short ${ }^{7}$ and simple. ${ }^{10}$ In this study, individuals with and without a diabetic family history who completed the detailed family history questionnaire (detailed condition) experienced no more time constraints than people who completed the simple enquiry. A possible explanation might be that addressing relatives' diabetes history enhances motivation for personal diabetes risk assessment, since it has been shown that people consider knowledge of family history important to their personal health. ${ }^{8}$ In this study, individuals who received either the simple or the detailed condition regarded the tool as equally useful and understandable, which underlines that the extra elaboration of a detailed questionnaire is no drawback. Furthermore those receiving general diabetes risk information with a simple enquiry had more worries than those completing a detailed family history assessment and receiving extended familial risk information. This suggests that explaining the role of familial risk moderates worries about diabetes risk.

Strength of this study was that the trial participants were not aware of being selected on their diabetic family history, as this attribute was being identified before the study. However, it should be noted that the items in the questionnaire refer to the Diabetes Risk Test and not familial risk assessment specifically. Generalization of the findings in this study should be done cautiously, since the population did not represent the ethnic mix of the Dutch population and represents only overweight individuals. Also, it should be noted that participants were rewarded with an incentive and were aware of participating in a scientific research. If the detailed family history assessment and information is provided in usual practice individuals might reserve less time for considering the information.

The findings in this study indicate that the use of a detailed familial risk questionnaire to diabetes risk assessments is perceived by users as valuable, and they would recommend it to others, without regarding it as too time consuming, suggesting that it is acceptable to use this tool in a public health approach. Besides, users of the detailed familial risk information perceived less feelings of worry than users who received a general diabetes risk assessment with a simple family history enquiry. Findings of this study may be relevant for other web-based risk assessment tools such as for cardiovascular diseases and cancer.

\section{Author statements}

\section{Acknowledgements}

This article is the result of a research project of the CSG Centre for Society and the Life Sciences and the Centre for Medical Systems Biology in The Netherlands.

\section{Ethical approval}

The VU University Medical Center Ethical Committee approved the study protocol.

\section{Funding}

This study was funded by the Netherlands Genomics Initiative (70.1.053.2h1).

\section{Competing interests}

No conflict of interest was reported by the authors of this paper.

\section{R E F E R E N C E S}

1. Claassen L, Henneman L, Janssens AC, Wijdenes-Pijl M, Qureshi N, Walter FM, et al. Using family history information to promote healthy lifestyles and prevent diseases; a discussion of the evidence. BMC Public Health 2010;10:248.

2. Ruffin MT, Nease Jr DE, Sen A, Pace WD, Wang C, Acheson LS, et al. Effect of preventive messages tailored to family history on health behaviors: the Family Healthware Impact Trial. Ann Fam Med 2009;9(1):3-11.

3. Pijl M, Timmermans DRM, Claassen L, Janssens ACJW, Nijpels G, Dekker JM, et al. Impact of communicating familial 
risk of diabetes on illness perceptions and self-reported behavioral outcomes: a randomized controlled trial. Diabetes Care 2009;32(4):597-9.

4. Wijdenes M, Henneman L, Qureshi N, Kostense PJ, Cornel MC, Timmermans DRM. Using web-based familial risk information for diabetes prevention: a randomized controlled trial. BMC Public Health 2013;13(485).

5. Cohn WF, Ropka ME, Pelletier SL, Barrett JR, Kinzie MB, Liu Z, et al. Health Heritage ${ }^{\oplus}$ a web-based tool for the collection and assessment of family health history: initial user experience and analytic validity. Public Health Genomics 2010;13(7-8):477-91.

6. Qureshi N, Armstrong S, Dhiman P, Saukko P, Middlemass J, Philip H, et al. Effect of adding systematic family history enquiry to cardiovascular disease risk assessment in primary care a matched-pair, cluster randomized trial. Ann Intern Med 2012;156(4):253-62.

7. Kalantar JS, Talley NJ. The effects of lottery incentive and length of questionnaire on health survey response rates: a randomized study. J Clin Epidemiol 1999;52(11):1117-22.

8. Centers for Disease Control and Prevention (CDC). Awareness of family health history as a risk factor for disease - United States. MMWR Morb Mortal Wkly Rep 2004;12:1044-7.

9. Alssema M, Feskens EJ, Bakker SJ, Gansevoort RT, Boer JM, Heine RJ, et al. Finnish questionnaire reasonably good predictor of the incidence of diabetes in The Netherlands. Ned Tijdschr Geneeskd 2008;152(44):2418-24.

10. Wilson P. How to find the good and avoid the bad or ugly: a short guide to tools for rating quality of health information on the internet. BMJ 2002;324(7337):598-600. 